\title{
Cross-border Downstream Benefit Sharing in Reservoir Type Hydropower Projects: Case of Budhi Gandaki Storage Project in Nepal
}

\begin{abstract}
This paper analyses the role of the principle of downstream benefit sharing under international water law regime in the management of cross-border water courses. This paper argues that the principle of downstream benefit sharing may play a key role in wiping away the long-existing distrust between countries as well as hold the potential to usher in a new phase of cooperation between riparian neighboring countries, such as Nepal and India. If pursued in good faith the downstream benefit principle would enjoin erstwhile losers of the vast potential to a cooperative mechanism where they could find themselves in a win-win situation. The Budhi Gandaki Storage Project presents a unique opportunity for employing this new paradigm of cooperation between two countries: Nepal and India. In this paper, we present the example of India that is facing a water and energy crisis for which it may ease to a considerable extent its problem by depending on Nepal for these resources. Downstream benefit sharing may provide India an opportunity to gain the confidence of the Nepalese people for developing many hydro projects with or without water augmentation resulting into multiple benefits downstream in India. Employing the downstream benefit sharing principle might require revisiting treaties like Gandak Project Agreement.
\end{abstract}

Key words: Storage project, downstream benefit principle, trans-boundary water cooperation, Nepal.

Attempts on Nepal India Water Cooperation ${ }^{1}$

Tntil today, there are three bilateral agreements between Nepal and India on water resource management: the Kosi Project Agreement (1954), Gandak Irrigation and Power Project Agreement (1959) and Mahakali Treaty (1996). The Kosi and Gandak Projects were completed by India under the Agreements. However, immediately after the conclusion of these agreements, they were criticized for being unfair to Nepalese interest (Devkota 1980). This perception has been based on the imbalance of the benefits that accrues to India as a result of these agreements. These agreements created an indelible scar of unfairness in the mind of Nepali people that could not be wiped out even by the Mahakali Treaty in 1996 which, unlike in the fifties when the decision was made during exclusive monarchy, was ratified by two-third majority in the Nepali Parliament (Upadhyay 2013). Unfortunately, The Mahakali Treaty was supposed to be much improved compared to its predecessor treaties, but this has not proven to be the case. Mahakali Treaty went to rough weather because of India's intransigent behavior regarding the interpretation and implementation of the Treaty's otherwise clear provisions. Thus, the Treaty again resulted in India reaping heavily one-sided benefits, and left the Pancheshwar Project (included in the Mahakali Treaty) in the lurch. Controversies over these three treaties have made water management a contentious issue between Nepal and India. And to date no meaningful harnessing of the vast water resources available to both the countries has materialized.

\section{International Experiences on Cross-border Down stream Benefit Sharing}

There are different successful cases around the world that demonstrate both the existence of the principle of cross-border downstream benefit sharing and its practical application.

\section{Columbia River Treaty}

The Columbia River Treaty, initiated in 1961 and ratified by the United States and Canada in 1964, was signed for a 60 year period, during which neither countries can terminate the agreement prior to the end date (2024). If one of the countries wants to terminate the Treaty at the end of the 60 year period, they are required to notify the other country 10 years in advance (Ofjord and Palmer 2002). The benefits accruing from these projects were classified as power, flood control and irrigation and each were shared equally. As a result of the Treaty, three dams (Duncan, Keenleyside and Mica) have been built on the Canadian side which store $19 \mathrm{BCM}$ of water each summer to provide downstream flows (Ofjord and Palmer 2002). As well, the US agreed to pay USD 64 million for downstream benefits accrued in their territory as a result of the Canadian Storage. Similarly, hydropower generated by these augmented waters was divided equally with Canada until the US bought the Canadian share for USD 254 million. The US is also required by the Treaty to utilize the flows from the Canadian storage in an efficient way to produce hydropower. In return for the building the dams, Canada is entitled to half of the additional hydropower benefits generated in the US parts of the river. So, Canada receives 50\% additional power from the US generated at 11 downstream hydropower stations in return for providing the regulated water through storage.

This Columbia River Treaty has been a pioneer example of mutual benefits sharing and co-operation between the riparian countries regarding transboundary water. This concept could be followed in regard to Nepal-India water relations. In fact, Nepal has 
always insisted on following the principles envisaged by the Columbia Treaty, all of which could be the basis to resolve outstanding issues with India. Application of these principles would provide the opportunity for Nepal to have a reasonable and equitable share in the use of the water resources (Verghese 1999).

\section{River Convention}

The riparian states of the Senegal River Basin (Mauritania, Senegal and Mali) entered into a Convention relating to the general development of the basin and the status of the Senegal River. The 1964 Convention also established a committee composed of representatives from the riparian states with powers over the development and use of the basin, and having the objectives to safeguard freedom of navigation. Then, in 1972, the governments of Mali, Mauritania and Senegal set up a river basin organization called the Organization pour la Mise en Valeur du Fleuve Senegal (OMVS in French). Guinea, the fourth basin country and with headwaters located within its territory, has recently joined the OMVS as well. The riparian countries have established the Senegal River Organization as a governing structure of planning and management to promote irrigation, power generation and navigation in the Senegal Valley.

Since the establishment of the Senegal River InterState Committee in 1963, and the agreement on the international status of the River and reformation into Organization for the Development of the Senegal River (OMVS) in 1972, riparian states have shown a willingness to cooperate within a very flexible framework based on the two key principles that: a) each state should have something to gain, and b) no state should be entirely dependent on another for access to the resources of the Senegal (GCI, 2000). Under the supervision and support of the OMVS, construction of Manantali dam (65m high and 146om long) on the Bafing River, a tributary of the Senegal River began in 1981 and completed in 1987. The purpose was to regulate flow of the Senegal River to a minimum flow of $300 \mathrm{~m}^{3} / \mathrm{s}$ in order to irrigate at least 275,000 ha of land, to generate hydropower of $800 \mathrm{GWh}$ per year, and to ensure a minimum flow of $100 \mathrm{~m}^{3} / \mathrm{s}$ on the last point downstream for all-season navigation on between the cities of St. Louis (Senegal) and Kayes (Mali). The dam has created a reservoir with storage capacity of $11.3 \mathrm{BCM}$ and a surface area of $477 \mathrm{~km}^{2}$. A power station of $200 \mathrm{MW}$ and a network of $1300 \mathrm{kms}$ of transmission lines to the capitals of Mali (Bamako), Mauritania (Nouakschott) and Senegal (Dakar) have been constructed.

One of the important aspects of this convention is that resources are not allocated to riparian states in terms of volumes of water to be withdrawn, but rather treated as a common resource with vast possibilities. This is backed up by a legal and regulatory framework established by the OMVS's fundamental conventions of 1972 and the Senegal River Water Charter signed in May 2002. This framework clearly states that the river water must be allocated to various use sectors. The management of the basin thus rests on principles of rational sharing of benefits in the utilization of resources. Another notable feature of this case is modality of funding. Two types of funding are used to finance development of the Senegal River basin. The first one covers operating costs of various OMVS bodies, and comes from three member states; each of them pays one third of the total in January of every year. To finance the jointly owned structures and other development activities, funds are sought in the form of loans extended either to the states or directly to the OMVS. In this case, the member states must guarantee the loans. Each member state ensures the reimbursement of its share of the loans.

The management of the Senegal River offers a unique example of benefit sharing between the riparian states. The benefits obtained and shared were in terms of irrigation, navigation and hydropower generation. This case shows how the developing co-riparian countries can cooperate for maximizing the benefits and how the states can jointly finance the major infrastructures for the development of the Transboundary Rivers. From this case we can conclude that the formation of the river basin organization, the clearly defined roles and duties of the organization and the rational share of the costs and benefits are the major reasons for the maximizing benefits and establishing cooperation among riparian states over the international rivers.

\section{Treaty on the Lesotho Highlands Water Project}

The Lesotho Highlands Water Project (LHWP) is a bi-national project between Lesotho and South Africa involving the export of water from Lesotho (through a series of dams and tunnels) to water-scarce Gauteng Province in South Africa. The LHWP is comprised of six major dams (in four phases) and associated infrastructure on the headwaters of the Senqu River in Lesotho, which becomes the Orange River as it crosses into South Africa (WWF, 2009). The signing of 'Treaty on the Lesotho Highlands Water Project' between the government of the Kingdom of Lesotho and the government of the Republic of South Africa in 1986 authorized the start of the project in which two parties committed themselves to the first two phases $1 \mathrm{~A}$ and $1 \mathrm{~B}$. The Katse Dam (185m high) in Lesotho is together with the Mohale Dam (145m) and $72 \mathrm{MW}$ hydropower plant form the key components for transferring water from Lesotho to South Africa.

According to the Treaty, South Africa will pay Lesotho royalties for water transferred and Lesotho will receive all hydroelectric power generated by the project. Article 12 (Royalty Payments) of the Treaty states that the royalty from the net benefit obtained is to be paid on the basis of $56 \%$ on the part of Lesotho and $44 \%$ of the part of South Africa. The net benefits are computed in accordance with the procedures set out by the 'Royalty Manual'. With the completion of Phase 1A of the project, Lesotho earned 5\% of its annual GDP (approximately 
USD 31 million) from transfer of water to South Africa (Sadoff and Gre, 2002). After the completion of Phase $1 \mathrm{~B}$, which increased the transfer rate of water from 18 $\mathrm{m}^{3} / \mathrm{sec}$ to $30 \mathrm{~m}^{3} / \mathrm{sec}$, the annual royalties received by Lesotho exceeded USD 80 million, which accounts for approximately $28 \%$ of total government revenue (WWF 2007). If all four of the envisaged phases are developed, the total water yield of the LHWP is expected to be in excess of $2.0 \mathrm{~km}^{3} / \mathrm{yr}$, which would generate annual royalty payments to Lesotho of about USD 100 million (WWF 2009). By 2011, Lesotho has already sold 7957.02 MCM of water to South Africa, which generated the total revenue of $3,347,051,689.72$ Maloti (or USD 424.75 million). So the average selling rate of per MCM of water comes to be around USD 53,381.

The LHWP presents a case about the transferral of waters of an entire river and does not exactly match the current situation of developing of reservoir type hydroprojects in Nepal. However, this Treaty does set up a new dimension on how a relatively weak riparian country, Lesotho, was enabled to make agreement with a powerful nation, South Africa, in which equity and fairness were obtained for both. Lesotho and Nepal have several similarities that are instructive in this regard. Both of these are small mountainous land-locked states and home to transboundary waters. Despite being upstream countries, both of these countries are economically reliant on downstream regional hegemons (South Africa and India).

These three cases presented above provide notable examples on the potential for sharing the benefits of trans-boundary rivers for development around the world. The success of these cases is guided mainly through the wider acceptance of the treaty or convention by the signing riparian countries and the adoption of the cross-border downstream benefit sharing principle. However, in the case of Nepal, the long history of mistrust with India regarding trans-boundary water resources highlights the challenges associated with managing such shared water resources. In addition, India's insistence on management control and refusal to allow independent assessment of downstream benefits has induced suspicion in Nepal (Chaturvedy and Malone 2011). Aside from the geo-political realities, the rapidly shifting population, and rising water demands, India's ascendance to economic and political superpower in the region makes negotiations on water issues difficult, though not impossible.

Geography complicates these negotiations further. As Nepal is situated on the headwaters of many rivers important to India, and is surrounded on three sides by India, all its waters drain into Indian territory. India has used this geographical advantage as leverage against matters of cooperation with Nepal, but this reflects a myopic view on India's part. A better cooperation and adjustment of legitimate demands might have contributed much to the economies of both the countries. Instead, the reality is that both India and Nepal are now suffering from shortages of energy and water.

\section{Reservoir Type Hydropower Projects in Nepal: The Budhi Gandaki Storage Project}

In the backdrop of the above examples, a new opportunity of meaningful cooperation between Nepal and India seems to be emerging in the shape of the Budhi Gandaki Storage Project (BGSP). The Budhi Gandaki River is a tributary of the Trishuli River in the central part of Nepal. The river originates from two main branches, one from the Lark Himal and the other, the Mowang Khola, from Tibet. After the confluence of these two branches, the river flows about $120 \mathrm{~km}$ to the south where it joins the Trishuli River. The catchment area in Tibet is approximately $1,750 \mathrm{~km}^{2}$ (SMEC 1979). The total catchment area of the basin at dam site is about 5,370 $\mathrm{km}^{2}$.

A high dam storage reservoir project is proposed on the Budhi Gandaki (Picture 1) primarily for the purpose of hydropower generation with a capacity of 600 MW. Prefeasibility study of this BGSP was done in early 1980's (MoWR, 1984). Per that study the project would involve construction of a $225 \mathrm{~m}$ high earth and rock-fill dam across the Budhi Gandaki river, about $2 \mathrm{~km}$ downstream of its confluence with Trishuli River at Benighat (about $79 \mathrm{~km}$ west from Kathmandu on the Prithvi Highway) to create a reservoir with an effective storage capacity of 2,755 Million Cubic Meter (MCM). The water from the reservoir would run to an underground power house with four turbines (each of 150 MW capacity) operating under a rated net head of $185 \mathrm{~m}$ for power generation (MoWR, 1984). The project would generate 2,496.6 GWh annually (NEA 2011). The underground powerhouse is to be located on the right bank of the Budhi Gandaki River in Ghalchowk VDC of Gorkha district.

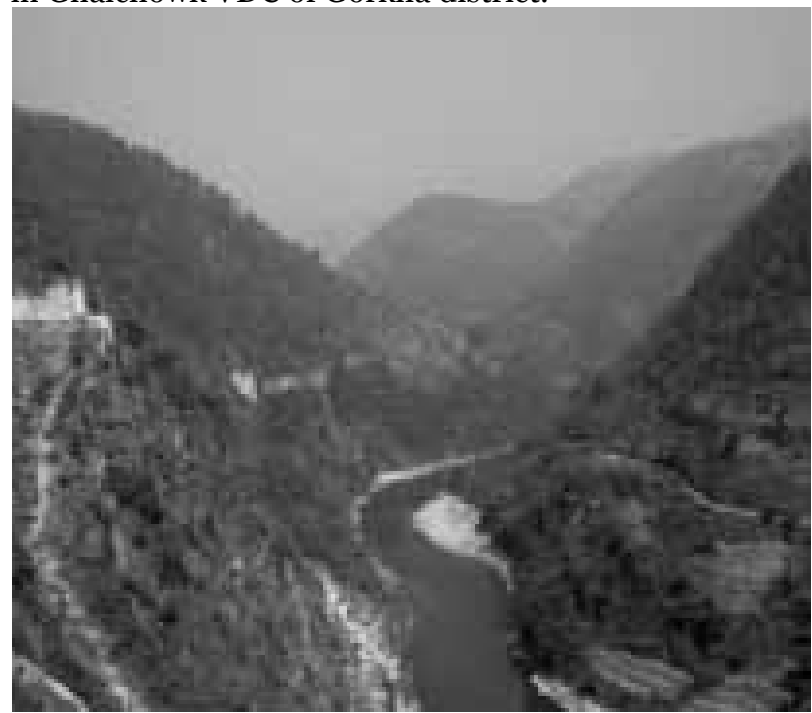

Photo 1. Proposed dam site of Budhi Gandaki Storage Project

BGSP will utilize the hydro-electric potential of the Budhi Gandaki River (a tributary of the Gandak River which is called the Narayani River before it enters India) for power generation in a storage type development. Since the Gandak River, like all major rivers of Nepal, 
drains into India, the river is a trans-boundary River. Nepal entered into a bilateral Treaty on the Gandak River in 1959, which was later amended in 1964. With the implementation of the Gandak Treaty, India has constructed the Gandak barrage at Nepal-India border (figure 1) mainly for the purpose of irrigation and flood control in India. The Treaty has been criticized within Nepal for limiting the benefits Nepal acquires from the Treaty. The Gandak Project irrigates 1,850,520 hectares of land in India whereas in Nepal it irrigates only 46,900 hectares, a meager 2.5 percent compared to what it irrigates in India (Pun 2007). According to the treaty, Nepal can withdraw the waters of Gandak River in any quantity for its use save that any trans-valley withdrawal for the months of February to April requires a separate agreement between the countries.

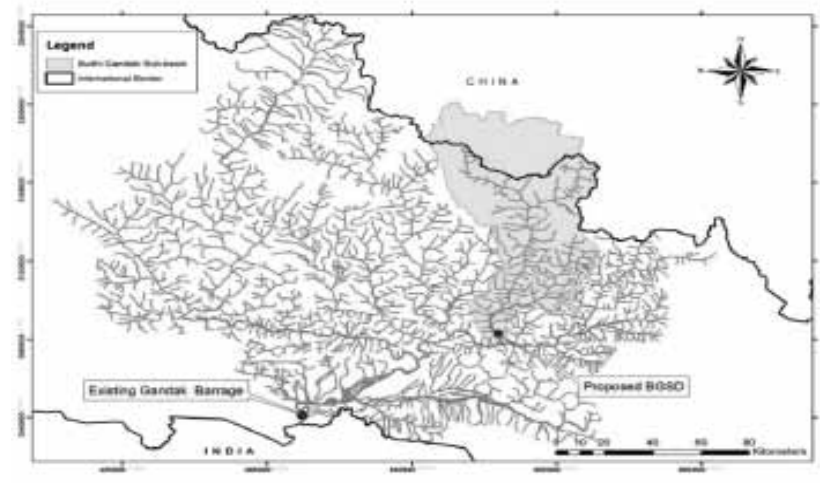

Figure 1. Map showing the drainage network of Gandak basin within Nepal and location of existing Gandak barrage and BGSP

Large dams such as Budhi Gandaki can be very beneficial in many aspects. The project can provide regulated flow to generate abundant hydroelectric energy (a total of 600 MW). Similarly, it would be possible to enhance agriculture production by supplying regulated water for irrigation in the dry season when the demand for water is the highest, mainly through the Gandak canals both in Nepal and India. Such regulation of water has become more important in the context of rising population and changing climate. The benefits of flood control and inland navigation are other benefits that could be gained by BGSP.

\section{Upstream Impacts of BGSP}

The reservoir of BGSP will cover an area of $49.8 \mathrm{~km}^{2}$ at full supply level (FSL) of 520m (MoWR, 1984). The high impact area includes areas of twenty-one Village Development Committees (VDCs) in the Dhading and Gorkha districts that will be inundated by the project. A preliminary environmental study carried out by ESSD-NEA (2010), estimated that 3347 ha of land will be inundated out of which $33.8 \%$ (1132 ha) consists of forest and $48.4 \%$ (1620 ha) consists of agricultural land. The study reported that altogether 42 settlements, 3,242 Households, 67 infrastructures (including 5 market centers) and 50 community forests will be affected within the 21 VDCs. This also means roughly 20,00o people will be displaced. Aarughat bazaar which extends both in Dhading and Gorkha districts will be submerged by the project.

\section{Quantifying Downstream Benefits}

Preliminary attempts have been made to quantify the potential downstream benefits of BGSP. Figure 2 shows the flow regulation before and after the execution of BGSP. With the execution of this project, a total of $1,670.46$ MCM of augmented water will be available annually during the dry season (October to May) which will be enough to irrigate some 80,000 ha of additional land in the downstream area (Gaudel 2013). This regulated water is more important for India whose population, and thus water demands, are growing. As per the estimates of the Ministry of Water Resources, Government of India, India's annual water demand will increase to 1,422 BCM by 2050 and India will require about 450 million tonnes of food grains per annum to feed a populationof 1.5 billion in the year 2050 (NCIWRD 1999). So, the regulated water thus obtained from storage project in Nepal is one of the means to meet India's growing water demand.

The figures of regulated water from BGSP mean that downstream in India substantially more water will be available for agriculture and other uses during the dry season, while during the monsoon it shall contribute substantially to flood control. This augmented water (1670.46 MCM from execution of BGSP) will worth USD 89.17 million annually if it is to be valuated on the basis of the principle set forth by the agreement between Lesotho and South Africa in the LHWP (Gaudel, 2013).

But it should be reiterated that these benefits are not without the cost. In exchange for the enhanced control and utilization of water, the BGSP will sacrifice a large swath of fertile land, create massive environment impact, require the resettlement of a huge population, incur a loss of property worth billions of rupees, and contribute to the psychological and socio-economic dislocation of many people. This cannot be understated.

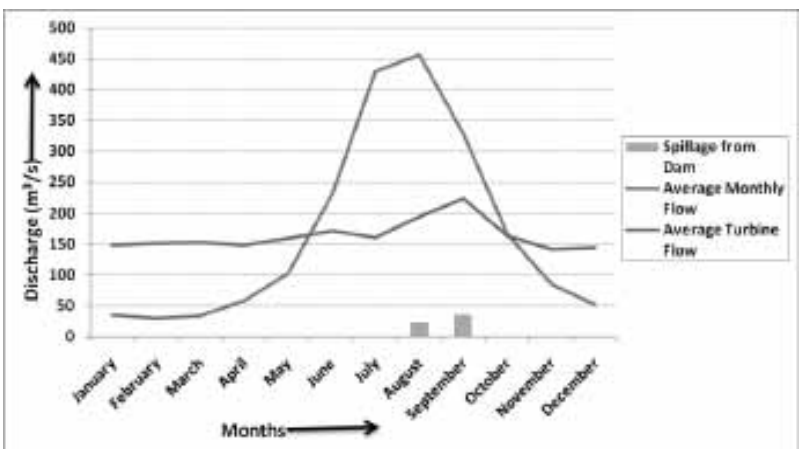

Figure 2. Flow Comparison Before and After Execution of BGSP (Source: NEA, 2011)

\section{Projected Plan to Spearhead BGSP Singularly as a Hydro Project}

At present BGSP seems to be intended as a single purpose power project. It has been argued that Nepal is in dire need of primary energy to feed in its huge 
seasonal energy gap and BGSP would provide a great measure to ease the problem. In fact, the annual peak power demand for the year 2012/13 was 1094.62 MW out of which only 607.1 MW could be supplied from hydropower generated within the country (NEA, 2013). In such a scenario of increasing energy demand (with an annual growth rate of about $9 \%$ ), the size and location of BGSP is ideal for such purposes. However, it must be asked if it is a good idea to build BGSP only for hydropower and ignore the huge benefits that would accrue through the rational management of the regulated flow. If such ancillary benefits are uncounted and the cost is singularly loaded to energy, then the cost of energy is going to be high. Moreover, there is a huge potential for power and energy trade within the sub-region of South Asia. In fact, Bangladesh, India and Bhutan have already taken a move in that direction and a crossborder transmission line is being built between India and Nepal which ultimately could be connected to the India-Bangladesh transmission corridor. Such initiatives would open a way for hydro-energy trade. In this respect one needs then to look at BGSP and similar projects as benefitting the region much like the Senegalese initiative (discussed above). In that respect the region benefits and no one loses: all countries gain and an exemplary action could be shown to the whole world. If thought within that context, all future projects could maximize the benefits of the reservoir projects by simulating operation not only in the context of power projects, but also as a project for supplying water and providing flood control. We should be reminded that there is no alternative to water.

\section{Principles of international law and the case of BSHP}

The principle of equitable sharing of the benefits in the use of international water watercourses among the riparian States is now a part of customary international law. Similarly, the principle of sharing the Downstream Benefits on international watercourses is equally recognized as principle of international law. In cases where agreements are made on the utilization of an international water course the provisions of the agreement are to be applicable. Where there is no agreement the dispute should be settled on the basis of customary international law. In the case of BSHP as stated earlier, the new regulated water added to the river due to BSHP is not covered by the existing Gandak Agreement between Nepal and India. The Gandak Agreement was basically designed to construct the Gandak Project and has a provision requiring separate agreement between upstream country Nepal and India for trans- valley diversion of the waters of the River during the months of February to April only. This means that the issue or the claim of sharing the benefits accruing out of regulated water from the BSHP is to be settled by the application of customary international law. Hence, the argument for sharing the benefits of regulated water downstream in India can well be based on international law.
The sharing of downstream benefits can also be analyzed from the point of the principle of unjust enrichment. The principle of Unjust Enrichment is developed in relation to private international law or the law of conflict. It is applicable in municipal jurisdictions also. This principle as has been the part of the principle of law practiced by civilized states it has now become applicable in settling international claims also. A situation to qualify as unjust enrichment it must be an enrichment of one party to the detriment of the other, and both must arise as a consequence of the same act or event. There must be no justification for the enrichment, and no contractual or other remedy available to the injured party whereby he might seek compensation from the party enriched. Thus the test of a situation for qualifying to be unjust enrichment would have five elements (1) an enrichment, (2) an impoverishment, (3) a connection between the enrichment and the impoverishment, (4) absence of a justification for the enrichment and the impoverishment (this has also been stated as "was the enrichment unjust?"), and (5) absence of a remedy provided by the law. If we apply these tests BSHP quite rightly fits into this situation. Not only that the regulated water by BSHP is out of the purview of Gandak Agreement if the downstream benefits of the regulated water is not counted and loaded on the other product and in this case the energy, the cost of energy is going to be high and Nepal would have to bear the burnt of it and India would be getting the benefits of the regulated flow without any cost to it and there is no justification for India to get this benefit free of cost. The Gandak Agreement has not perceived this situation. Hence, there is a strong case for a claim on the downstream benefits out of the regulated water from the BSHP. BSHP presents a choice. Nepal and India may negotiate the sharing of the downstream benefits accruing to India out of the regulated flow and create faith and trust for more mutual benefits from many hydro power and other water related projects in the future or live with a sense of loss and non-cooperation.

\section{Conclusions and Way Forward}

The adoption of the downstream benefit principle can play a positive role in turning historical legacies of distrust to ones of renewed faith and friendliness. If Nile River sharing countries can leave behind bold agreements; if the US and Canada can agree to share downstream benefits of the Columbia River; if South Africa can pay royalties to Lesotho for water supply and storage; if Senegal, Mali and Mauritania can agree to construct a reservoir to share the benefits in the Senegal River then why can't Nepal and India cooperate in matters of the use of the water from the Budhi Gandaki Storage Project (BGSP)? It may be hoped that common sense will prevail among the policy makers in both countries so as not to lose the opportunity to correct the unfair course of the Gandak Treaty. After all, projects of the nature of BGSP have vast potential to provide both material and symbolic benefits to Nepal and India. Unless we use these opportunities to restore this trust and good faith, 
the potential to develop other projects based on water resources for Nepal and India will be a mirage.

Surya Nath Upadhyay $L L M$, from London University served the Government of Nepal for more than three decades and held various important and critical positions such as Secretary, Ministry of Water Resources, Chief Commissioner of the Commission for the Investigation of Abuse of Authority etc. During his career of civil servant, he remained involved in water resources for many years and preformed various roles - adviser, negotiator and decision maker. He has published several reports, articles and books, the recent one being a book entitled International Watercourses Law and A perspective of Nepal-India Cooperation. Presently, he is associated with JVS, a civil society organization for water resources development.

Corresponding address: mail@jvs.org.np or suryanathupadhyay@gmail.com

Prakash Gaudel works as Environment Specialist at Environment and Social Studies Department, Nepal Electricity Authority since 2011. He holds M.Sc. degrees in Interdisciplinary Water Resources Management from Nepal Engineering College (Pokhara University) and M.Sc. in Environment Science from Kurukshetra University, India.

Corresponding address: prakgaudel@gmail.com

\section{References}

Chaturvedy, R. R. and Malone, D. M. 2011. Hydrodiplomacy: A neglected opportunity for Nepal and India. In: The Hindu, (June 27, 2011). Available at http://www.thehindu.com/opinion/ op-ed/ hydrodiplomacy-a-neglected-opportunity-for-nepaland-india/article2139749.ece

Devkota, G. B. 1980. Nepal Ko Rajnitik Darpan, Vol. 2-A book on the Political Scenario of Nepal. Jaya Bharat Press Bans Phatak, Baransi, India.

ESSD-NEA 2010. Environmental Consideration of Budhi Gandaki Storage Hydroelectric Project. Environment and Social Studies Department, Nepal Electricity Authority, Kathmandu.

Gaudel, P. 2013. Budhi Gandaki Storage Project: A Single Purpose or Strategic Project?- In context of Increasing Climatic Uncertainties. In: Vidyut. Year 24 (1), Nepal Electricity Authority, Kathmandu, Nepal, pp 77-82.

GCI, 2000. National Sovereignty and International Watercourses.Green Cross International. Geneva, Switzerland.

MoWR 1984. BurhiGandaki Hydroelectric ProjectPrefeasibility Study. Main Report, Vol. (I), Electricity Department, Ministry of Water Resources, Kathmandu.

NCIWRD 1999 .Integrated Water Resources Development- A Plan for Action. Report ofthe National Commission for Integrated Water Resource Development Volume I, Ministry ofWater Resources.
Government of India, New Delhi.

NEA 2011. Budhi Gandaki Hydroelectric ProjectReview Report. Project Development Department, Engineering Services, Nepal Electricity Authority, Kathmandu, Nepal.

NEA 2013.A Year in Review-Fiscal Year 2012/2013. Nepal Electricity Authority, Kathmandu, Nepal.

Ofjord, G.D. and Palmer, R. 2002. Use of Computer Models in Management and Negotiation of International Water Resources. In: Proceedings- From Conflict to Co-operation in International Water Resources Management: Challenges and Opportunities (ed. S. Castelein). International Conference, UNESCO-IHE Institute for Water Education, Delft, The Netherlands.

Pun, S.B. 2007. Whither Indo-Nepal Water Resources? Part III- Issues and Episodes to Reflect on Gandak River: Indo-Nepal Gandak Treaty, Amendment and Gandak Master Plan Study. Vidyut. Year18 (1), Nepal Electricity Authority, Kathmandu, Nepal, pp. 1-11.

Sadoff, C.W. and Grey, D. 2002. Beyond the River: The Benefits of Cooperation on International Rivers. Water Policy 4, Elsevier Science Ltd., pp. 389-403.

SMEC 1979.Gandak River Basin Power Study -Basin Study- Basin Master Plan.Vol.I, Main Report. Commissioned for GoN by UNDP, prepared by SMEC in association with Environmental planning Associates and supported by Nepal Electricity Authority.

Upadhyay, S.N. 2012. International Watercourses Law and a Perspective on Nepal-India Cooperation. Ekta Books, Kathmandu, Nepal.

Upadhyay, S.N. 2013. Waters that bind In: The Republica (October24, 2013). Available at: http://www. myrepublica.com/portal/index.php?action=news_ details\&news_id=63432

Verghese, B.G. 1999. Water of Hope- From Vision to Reality in Himalaya Ganga Development Cooperation. Oxford and IBH Publishing House, New Delhi.

WWF, 2009. Interbasin Water Transfers and Water Scarcity in a Changing World - A Solution or a Pipedream?A Discussion Paper for a Burning Issue, second edition (eds. J. Pittock, J. Meng, M. Geiger and A.K. Chapagain), WWF Germany.

WWF, 2007. Pipedreams? Interbasin Water Transfers and Water Shortages. WWF Global Freshwater Programme, Netherlands.

Vohryzek-Griest, Ana T., "Unjust Enrichment Unjustly Ignored: Opportunities and Pitfalls in Bringing Unjust Enrichment Claims Under ICSID" (2008). Student Scholarship Papers. Paper 72. http.// digitalcommons.law.yale.idu/student_papers/72

\section{Footnote}

1. In this paper, the words cross-border, transboundary and international water courses are used synonymously or interchangeably for any water bodies flowing from one country to other. 